\title{
Evaluating the role of high-sensitivity C-reactive protein in asthmatic Iraqi patients and its correlation with parameters of patients' clinical characteristics and pulmonary function tests
}

\author{
Muhammed Saleh Najdat', Ahmed M Lutfi ${ }^{2}$ \\ ${ }^{1}$ Medical doctor, Specialist of Internal Medicine, M.D., Fellow of Iraqi Board of Medical Specialties, Member of Royal College of \\ Physicians (United Kingdom), Faculty of Internal Medicine, Baghdad Medical City Teaching Complex, Baghdad, IRAQ, ${ }^{2}$ Medical \\ doctor, Anatomist, Dermatologist, and Information Technology Associate, MD, PG-Cert (United States), PG-Diploma (United Kingdom), \\ M.Sc. (United Kingdom), Member of European Academy of Dermatology and Venereology (EADV), Member of National Academy of \\ Neuropsychology (NAN), Member of American Association of Anatomists (AAA), Department of Pathology and Forensic Medicine, College \\ of Medicine, Baghdad University
}

Aims and Objectives: To evaluate the relevance of high-sensitivity assays for C-reactive protein (hs-CRP), as a sensitive marker of inflammation in asthmatic Iraqi patients. Additionally, correlations of serum levels of hs-CRP with patients' clinical characteristics and pulmonary function tests (PFTs) will be studied in a cross-sectional design. Materials and Methods: A random sample of 58 individuals were divided into a healthy (control) group $(n=12)$ and two groups of adult patients with chronic stable asthma; $(n=22)$ patients had been receiving inhaled corticosteroids (inhaled corticosteroid-positive, or ICS + VE group) for the past 2-3 months, and $(n=24)$ steroid-naive patients (inhaled corticosteroidnegative, or ICS-VE, group). The selected individuals were subjected to hs-CRP measurement and PFTs. Results: The forced expiratory volume in one second $\left(\mathrm{FEV}_{1}\right) /$ forced vital capacity (FVC) was measured in all subjects. In the ICS + VE and the ICS-VE groups, there was a significant correlation between the level of hs-CRP and FEV $/$ FVC with $\mathrm{r}$ : -0.891 and a p-value of $<0.0005$ for both groups. In the ICS-VE group, $78.5 \%$ had significant clinical symptoms, whereas only $22.7 \%$ of the ICS + VE group had significant clinical symptoms. This difference (for the prevalence of clinical symptoms) was significant with a chi-square value of 19.59, degree of freedom (df) $=1$, and $p<0.0005$. Conclusion: In the ICS-VE group, the level of hs-CRP was significantly higher than in both the ICS + VE group and the control group. The values of the PFTs were significantly lower in the ICS-VE group. The prevalence of clinical features was significantly higher in the ICS-VE group.

Key words: High-sensitivity C-reactive protein, Asthma, Obstructive, Corticosteroids, Inflammation, Iraq

\section{INTRODUCTION}

Asthma is a chronic inflammatory disorder that results in recurrent episodes of breathing difficulties, and coughing, mainly at night or in the early morning. Boys are affected more commonly than girls. However, after puberty, females are affected slightly more. ${ }^{1-6}$

\section{Access this article online}

Website:

http://nepjol.info/index.php/AJMS DOI: 10.3126/ajms.v7i3.13880 E-ISSN: 2091-0576 P-ISSN: $2467-9100$

\section{Asthma and $\mathrm{C}$-reactive protein}

CRP is an acute-phase protein that can be simply and inexpensively measured to assess systemic inflammation. Standard CRP assays are not sensitive enough. Recently, assays for high-sensitivity C-reactive protein (hs-CRP) have become available. Many studies, concluded that hs-CRP levels are strongly associated with asthma. ${ }^{7-10}$ 


\section{Pathophysiology}

The pathologic changes can be patchy, and without an extension to lung parenchyma. A characteristic finding is basement membrane thickening due to the sub epithelial deposition of collagen. Triggering factors, in susceptible patients, induce a hypersensitivity reaction with an early and/or late-phase pulmonary response. Both phases depend on allergen-specific immunoglobulin $\mathrm{E}(\mathrm{IgE})$. Bronchospasm in the late phase is mediated by the infiltrating cells' soluble factors. ${ }^{2,3,5}$

\section{Clinical features}

The symptoms are often triggered by exercise, allergen, or viral respiratory infections. The triad of wheezing, chest tightness, and shortness of breath is characteristic of asthma. One or more of these symptoms are reported in $90 \%$ of patients. The most characteristic finding of asthma is polyphonic expiratory wheezing, which requires respiratory effort. Over-inflation of the thoracic cage may be obvious. ${ }^{1,4,11}$

\section{Diagnosis}

The diagnosis is largely based on the presence of: characteristic triad of Symptoms; Day-to-day peak flow variability ( $>15 \%$ variability, or reversibility to inhaled beta- 2 agonist); and other parameters of pulmonary function tests. ${ }^{11,12}$

\section{Management}

The main drugs for asthma are divided into bronchodilators and controllers. ${ }^{3}$

\section{Bronchodilator therapy}

These are: Beta-2 (B2)-adrenergic agonist, anticholinergics, and theophylline. B2-agonists are the most effective. ${ }^{3,13-17}$

\section{$B 2$ agonist}

\section{A. short-acting B2 agonist}

These bronchodilators are the most effective in the symptoms of a sudden asthma attack..$^{3,13-15}$

\section{B. Long-acting B2 agonist}

Long-acting bronchodilators are used in conjunction with inhaled steroids to achieve long-term asthma control; if used alone, they can cause death. ${ }^{15}$

\section{Anticholinergics}

Anticholinergic agents have been used with beta-agonists for the emergency control of acute asthma. ${ }^{14,16}$

\section{Theophyllines}

Theophylline use has now fallen due to its safety profile. ${ }^{3,17}$

\section{Controller therapies Inhaled corticosteroids}

Inhaled corticosteroids are the main therapeutic modality for the long-term control of asthma. Their use has been associated with. ${ }^{18-20}$

\section{Anti-leukotrienes}

Leukotriene (LT) pathway inhibitors may substitute ICS in selected patients with mild asthma in which Steroids are not well-tolerated or not desired by the patient. Furthermore, anti-leukotrienes are useful as steroid-sparing agents in moderate-to-severe asthma., ${ }^{1,4,6}$

\section{Chromones}

They are very effective in trigger-induced asthma. Nedocromil was proven to be effective in children with chronic mild-to-moderate asthma., ${ }^{4,21}$

\section{Anti-lgE}

Omalizamub, a humanized anti-IgE antibody, is very effective in moderate-to-severe asthma by reducing exacerbations, improving lung function, and acting as a steroid-sparing agent. ${ }^{3,4}$

\section{AIMS OF THE STUDY}

1. Evaluation of hs-CRP as a marker of systemic inflammation in asthma.

2. Study the correlation between hs-CRP, clinical characteristics, and the pulmonary function test in asthma.

3. Study the effect of ICS on both PFTs and the level of hs-CRP.

\section{MATERIALS AND METHODS}

\section{Study sample}

A random sample of 58 persons was divided into healthy(control) group $(n=12)$ and two groups of adult patients with chronic stable asthma; $22(n=22)$ patients had been receiving ICS(400-600 micrograms per day of chlorofluorocarbon [CFC]-beclomethasone dipropionate) (inhaled corticosteroid-positive, or ICS+VE group) for the past 2-3 months, and $24(\mathrm{n}=24)$ steroid-naive(inhaled corticosteroid-negative, or ICS-VE) patients had been treated with inhaled short-acting B2agonist (as required). The asthmatic patients were randomly selected from the outpatient clinic of the faculty of internal Medicine at Baghdad Medical City Teaching Complex. Individuals allocated to the control group were randomly selected from the medical and paramedical staff within the same hospital. None of the patients were smokers or had respiratory tract infections or exacerbations of asthma in the month prior to enrolment in the study. Individuals with diabetes mellitus, cardiac disease, malignant status, systemic disorders, or obesity with a body mass index (BMI) equal to or more than 30\% and systemic disorders were excluded. The selected individuals were subjected to the measurement of hs-CRP and PFTs. Thorough history and clinical examination was also performed. 
Study design

\section{A cross-sectional design}

Diagnostic criteria for asthma

The diagnosis of asthma was considered based on the clinical history of variable and intermittent airway obstruction combined with demonstration of airway variability measured using the reversibility test, which is defined as an increment of more than $12 \%$ (or $200 \mathrm{ml}$ ) of FEV1 after 15 minutes of administration of inhaled short-acting B2agonist (according to the British guidelines on the management of asthma).

\section{Measurement of high-sensitivity C-reactive protein $^{9,10,22}$}

Samples of peripheral venous blood were aspirated (5 milliliters), put in a plane tube, and centrifuged at 3000x g at $4 \mathrm{C}$ for 5 minutes. The sera were placed in tightly sealable container and stored at $-20 \mathrm{C}$ (repeated freezing and thawing was avoided).

Serum hs-CRP was quantified using a highly sensitive-CRP assay (Cormay CRP U MULTICALIBRATOR), lot 906-21 exp 2011-05, with kit lot no. 909-20 C EXP 2010-12, CE. The reference value was $<1 \mathrm{mg} / \mathrm{dl}$, with Analytical range of $0.01-32 \mathrm{mg} / \mathrm{dl}$.

\section{Pulmonary function test}

Pre-bronchodilatory FEV1 and FEV1/forced vital capacity (FVC) were measured using office spirometry in the pulmonary function test/outpatient clinic in Baghdad Teaching Hospital at the Baghdad Medical City Teaching Complex.

\section{Statistical analysis}

SPSS (Statistical Package for Social Sciences) version 19 was used for data input and analysis. For independent samples, a t-test was used to estimate the significance of difference between two continuous variables. Pearson's correlation coefficient was utilized to estimate the significance of relation between two continuous variables. A p value of less than 0.005 was considered significant.

\section{RESULTS}

Table 1 shows the control group and the two groups of asthmatic patients; the inhaled corticosteroid-positive (ICS+VE) and inhaled corticosteroid-negative (ICS-VE) groups. Demographic parameters are shown together with the PFTs, and serum level of hs-CRP. In the control group, there was an equal sex distribution ( 6 males, 6 females); in the ICS+VE group, there were 8 males and 14 females, and in the ICS-VE group, there were 11 males and 13 females. Disease duration in the ICS+VE and ICS-VE groups was almost comparable $-15.1 \pm 3.9$ years and $14.6 \pm 4.2$ years, respectively. The FEV1/FVC in than ICS+VE group was significantly higher than in the ICS-VE group $(73.5 \pm 2.4$ for ICS+VE vs. 67.9 \pm 2.3 for ICS-VE with $\mathrm{p}:<0.0005)$. The serum hs-CRP in the ICS-VE group was significantly higher than that of the ICS+VE group $(2.7 \pm 0.3 \mathrm{mg} / \mathrm{dl}$ for ICS-VE vs. $1.3 \pm 0.1 \mathrm{mg} / \mathrm{dl}$ for ICS $+\mathrm{VE}$ with $\mathrm{p}:<0.0005$, and $0.5 \pm 0.2 \mathrm{mg} / \mathrm{dl}$ for the control group with $\mathrm{p}:<0.0005)$. The serum hs-CRP in the ICS+VE group was significantly higher than that of the control group with $\mathrm{p}<0.05$.

Table 2 shows the correlations between serum hs-CRP and other parameters in the ICS+VE and the ICS-VE groups. There was a significant correlation between the serum level of hs-CRP and $\mathrm{FEV}_{1} / \mathrm{FVC}$, with $\mathrm{r}:-0.891$ and $\mathrm{p}:<0.0005$ for both groups.

Concerning the clinical characteristics, the relation of significant clinical symptoms among the two asthmatic groups; in the ICS-VE group, $78.5 \%$ had significant clinical symptoms, whereas only $22.7 \%$ of the ICS +VE group had significant clinical symptoms.

Table 3 illustrates the correlation of multiple variables among the ICS+VE group with their corresponding Confidence Interval (CI); the correlation between hs-CRP and $\mathrm{FEV}_{1} / \mathrm{FVC}$ had an inverse relation and was significant with a $99 \%$ confidence interval (CI).

\begin{tabular}{|c|c|c|c|}
\hline & \multicolumn{2}{|c|}{ Asthma } & \multirow[t]{2}{*}{ Control } \\
\hline & ICS+ & ICS- & \\
\hline Subjects $n$ & 22 & 24 & 12 \\
\hline Age (years) & $45.8 \pm 4.9$ & $43.1 \pm 6.2$ & $32.0 \pm 4.3$ \\
\hline Gender (M/F) & $8 / 14$ & $11 / 13$ & $6 / 6$ \\
\hline Disease duration (years) & $15.1 \pm 3.9$ & $14.6 \pm 4.2^{+}$ & \\
\hline $\mathrm{FEV}_{1} / \mathrm{FVC}$ & $73.5 \pm 2.4$ & $67.9 \pm 2.3^{8}$ & \\
\hline BMI & $25.6 \pm 2.4$ & $25.4 \pm 2.0$ & $25.8 \pm 2.1$ \\
\hline hs-CRP mg/dl & $1.3 \pm 0.1$ & $2.7 \pm 0.3^{\#}$ & $0.5 \pm 0.2^{\# \#}$ \\
\hline
\end{tabular}

\begin{tabular}{|c|c|c|c|c|}
\hline & \multicolumn{4}{|c|}{ Serum hs-CRP mg/dl } \\
\hline & \multicolumn{2}{|c|}{ ICS+VE } & \multicolumn{2}{|c|}{ ICS-VE } \\
\hline & $\mathbf{R}$ & $P$ value & $\mathbf{R}$ & $P$ value \\
\hline Subjects $\mathrm{n}$ & 22 & & 24 & \\
\hline Age (years) & -0.139 & 0.537 & -0.201 & 0.347 \\
\hline BMI $\mathrm{kg} / \mathrm{m}^{2}$ & 0.18 & 0.19 & 0.230 & 0.280 \\
\hline $\mathrm{FEV}_{1} / \mathrm{FVC}$ & -0.891 & $<0.0005$ & -0.891 & $<0.0005$ \\
\hline Disease duration (years) & 0.071 & 0.755 & 0.016 & 0.941 \\
\hline
\end{tabular}

ICS+VE correlation significant with FEV /FVC only, ICS-VE correlation significant with $\mathrm{FEV}_{1} / \mathrm{FVC}$ only 
Table 4 illustrates the correlation of multiple variables among the ICS-VE group with their corresponding CIs; the correlation between hs-CRP and $\mathrm{FEV}_{1} / \mathrm{FVC}$ had an inverse relation and was significant with a 99\% CI. Results of Chi-square tests and group statistics are demonstrated in Tables 5 and 6 .

Figure 1 shows the serum levels of hs-CRP among the three groups represented as mean \pm standard deviation, $0.5 \pm$
$0.2 \mathrm{mg} / \mathrm{dl}$ for control, $1.3 \pm 0.1$ for the ICS+VE group, and $2.7 \pm 0.3 \mathrm{mg} / \mathrm{dl}$ for the ICS-VE group.

Figure 2 shows a scattered diagram representing the relation between $\mathrm{FEV}_{1} / \mathrm{FVC}$ and the serum level of hs-CRP in the ICS+VE group; the relationship is an inverse relationship.

Figure 3 shows a scattered diagram representing the relation between $\mathrm{FEV}_{1} / \mathrm{FVC}$ and the serum level of hs-

\begin{tabular}{|c|c|c|c|c|c|}
\hline & Age & BMI & hs-CRP & FEV $_{1} / \mathrm{FVC}$ & Duration \\
\hline \multicolumn{6}{|l|}{ Age } \\
\hline Pearson correlation & 1 & 0.048 & -0.139 & 0.057 & $0.649^{* *}$ \\
\hline Sig. (2-tailed) & & 0.833 & 0.537 & 0.800 & 0.001 \\
\hline $\mathrm{N}$ & 22 & 22 & 22 & 22 & 22 \\
\hline \multicolumn{6}{|l|}{ BMI } \\
\hline Pearson correlation & 0.048 & 1 & 0.12 & -0.13 & 0.148 \\
\hline Sig. (2-tailed) & 0.833 & & 0.16 & 0.43 & 0.512 \\
\hline $\mathrm{N}$ & 22 & 22 & 22 & 22 & 22 \\
\hline \multicolumn{6}{|l|}{ hs-CRP } \\
\hline Pearson correlation & -0.139 & 0.18 & 1 & $-0.891^{\star *}$ & 0.071 \\
\hline Sig. (2-tailed) & 0.537 & 0.68 & & $<0.0005$ & 0.755 \\
\hline $\mathrm{N}$ & 22 & 22 & 22 & 22 & 22 \\
\hline \multicolumn{6}{|l|}{ FEV1/FVC } \\
\hline Pearson correlation & 0.057 & -0.13 & $-0.891^{* *}$ & 1 & -0.065 \\
\hline Sig. (2-tailed) & 0.800 & 0.43 & $<0.0005$ & & 0.774 \\
\hline $\mathrm{N}$ & 22 & 22 & 22 & 22 & 22 \\
\hline \multicolumn{6}{|l|}{ Duration } \\
\hline Pearson correlation & 0.16 & 0.148 & 0.071 & -0.065 & 1 \\
\hline Sig. (2-tailed) & 0.64 & 0.512 & 0.755 & 0.774 & \\
\hline $\mathrm{N}$ & 22 & 22 & 22 & 22 & 22 \\
\hline
\end{tabular}

$* *$ Correlation is significant at the 0.01 level (2-tailed)

\begin{tabular}{|c|c|c|c|c|c|}
\hline & Age & BMI & hs-CRP & FEV $_{1} /$ FVC & Duration \\
\hline \multicolumn{6}{|l|}{ Age } \\
\hline Pearson correlation & 1 & -0.209 & -0.201 & 0.308 & 0.12 \\
\hline Sig. (2-tailed) & & 0.326 & 0.347 & 0.144 & 0.43 \\
\hline $\mathrm{N}$ & 24 & 24 & 24 & 24 & 24 \\
\hline \multicolumn{6}{|l|}{ BMI } \\
\hline Pearson correlation & -0.209 & 1 & 0.230 & -0.402 & 0.027 \\
\hline Sig. (2-tailed) & 0.326 & & 0.280 & 0.052 & 0.902 \\
\hline $\mathrm{N}$ & 24 & 24 & 24 & 24 & 24 \\
\hline \multicolumn{6}{|l|}{ hs-CRP } \\
\hline Pearson correlation & -0.201 & 0.230 & 1 & $-0.891^{\star *}$ & 0.016 \\
\hline Sig. (2-tailed) & 0.347 & 0.280 & & $<0.0005$ & 0.941 \\
\hline $\mathrm{N}$ & 24 & 24 & 24 & 24 & 24 \\
\hline \multicolumn{6}{|l|}{$\mathrm{FEV}_{1} / \mathrm{FVC}$} \\
\hline Pearson correlation & 0.308 & -0.402 & $-0.891^{* *}$ & 1 & -0.151 \\
\hline Sig. (2-tailed) & 0.144 & 0.052 & $<0.0005$ & & 0.481 \\
\hline $\mathrm{N}$ & 24 & 24 & 24 & 24 & 24 \\
\hline \multicolumn{6}{|l|}{ Duration } \\
\hline Pearson correlation & 0.12 & 0.027 & 0.016 & -0.151 & 1 \\
\hline Sig. (2-tailed) & 0.43 & 0.902 & 0.941 & 0.481 & \\
\hline $\mathrm{N}$ & 24 & 24 & 24 & 24 & 24 \\
\hline
\end{tabular}




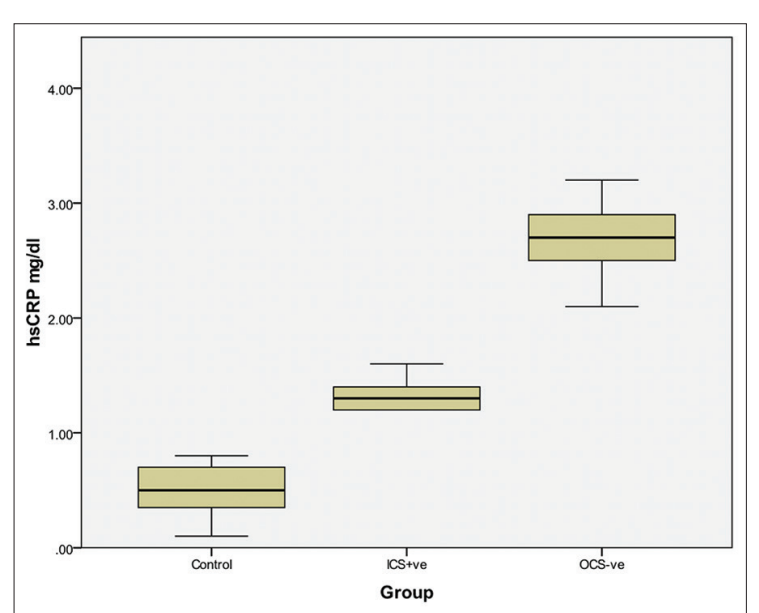

Figure 1: Mean and standard deviation of serum hs-CRP among asthmatics and control groups

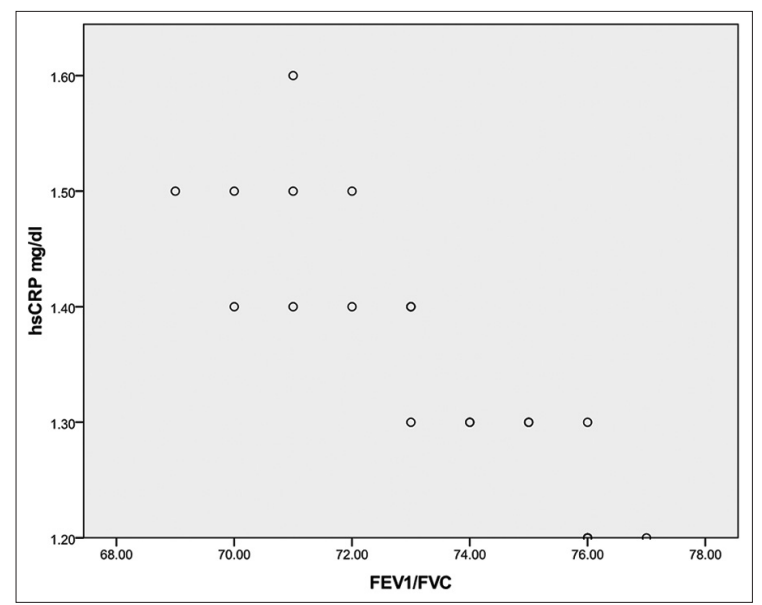

Figure 2: Scattered diagram showing relation between serum hs-CRP and $\mathrm{FEV}_{1} / \mathrm{FVC}$ in ICS+VE group

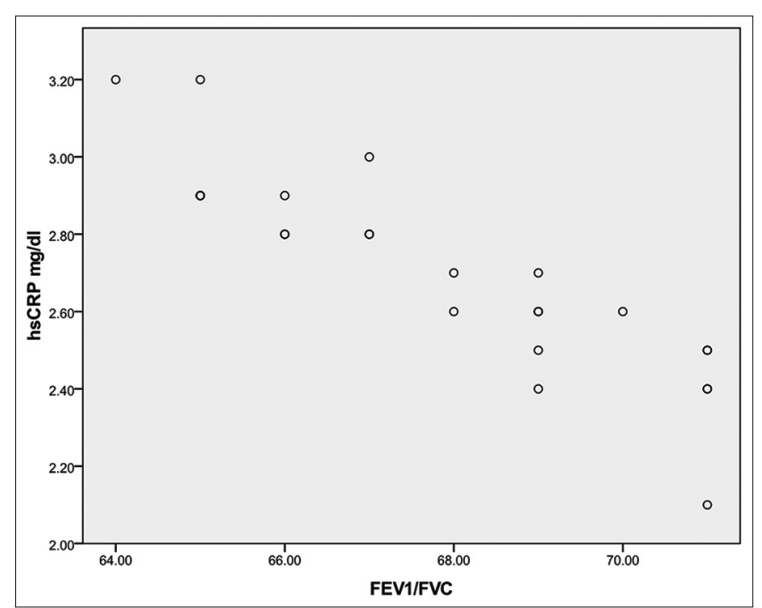

Figure 3: Scattered diagram illustrating relation between serum hs-CRP and FEV1/FVC in ICS-VE group

CRP in the ICS-VE group; the relationship is an inverse relationship.

\begin{tabular}{lccc}
\multicolumn{4}{l}{ Table 5: Chi-square tests } \\
\hline & Value & df & Asymp. Sig. (2-sided) \\
\hline Pearson Chi-Square & 0.713 & 2 & 0.700 \\
\hline
\end{tabular}

\begin{tabular}{|c|c|c|c|c|c|}
\hline \multicolumn{6}{|c|}{ Group statistics } \\
\hline & Type & $\mathbf{N}$ & Mean & $\begin{array}{c}\text { Std. } \\
\text { deviation }\end{array}$ & $\begin{array}{l}\text { Std. error } \\
\text { mean }\end{array}$ \\
\hline \multirow[t]{2}{*}{$\mathrm{FEV}_{1} / \mathrm{FVC}$} & ICS+VE & 22 & 73.4545 & 2.42462 & 0.51693 \\
\hline & ICS-VE & 24 & 66.6250 & 6.30950 & 1.28792 \\
\hline \multirow[t]{2}{*}{ Duration } & ICS+VE & 22 & 15.0909 & 3.90249 & 0.83201 \\
\hline & ICS-VE & 24 & 14.5833 & 4.17983 & 0.85321 \\
\hline \multicolumn{6}{|c|}{ Independent samples test } \\
\hline & \multicolumn{5}{|c|}{ t-test for equality of means } \\
\hline & $\mathbf{t}$ & & Df & \multicolumn{2}{|c|}{ Sig. (2-tailed) } \\
\hline $\mathrm{FEV}_{1} / \mathrm{FVC}$ & 4.761 & & 44 & \multicolumn{2}{|c|}{$<0.0005$} \\
\hline Duration & 0.425 & & 44 & \multicolumn{2}{|c|}{0.673} \\
\hline
\end{tabular}

\section{DISCUSSION}

In this cross-sectional study, the results have high levels of agreement with other studies, including those of: Kony et al., ${ }^{8}$ Shimoda et al. ${ }^{1,0}$ Razi et al., ${ }^{9}$ and Kamath et al. ${ }^{7}$ However, Ramirez et al. ${ }^{22}$ study on patients with asthma, mostly of a mild severity, did not reveal any significant correlation between hs-CRP with asthma, wheezing, National Asthma Education and Prevention Program (NAEPP) control score, forced expiratory volume in one second (FEV1), or fractional exhaled nitric oxide $(\mathrm{FeNO}) \cdot^{7-10,22}$

We studied the validity of hs-CRP in patients with asthma and its relationship to the clinical characteristics and the degree of airway inflammation. In our study, the sample was divided into three groups, the control, the steroid-positive (ICS+VE), and the steroid-negative (ICS-VE) groups. The age in the control group was less than that of the two asthmatic groups, with a value of $32 \pm 4.3$ years for the control group and $43.1 \pm 6.2$ years and $45.8 \pm 4.9$ years for the ICS-VE and ICS+VE groups, respectively. The disease duration in the ICS+VE group was $15.1 \pm 3.9$ years and 14.6 \pm 4.2 in the ICS-VE group. The BMI was almost comparable among the three groups, at $25.6 \pm 2.4 \mathrm{~kg} / \mathrm{m}^{2}, 25.4 \pm 2 \mathrm{~kg} / \mathrm{m}^{2}$, and $25.8 \pm 2.1 \mathrm{~kg} / \mathrm{m}^{2}$ in the ICS+VE, ICS-VE, and control groups, respectively. The BMI did not exceed $30 \mathrm{~kg} / \mathrm{m}^{2}$ because any patient with a BMI of $>30 \mathrm{~kg} / \mathrm{m}^{2}$ had already been excluded from the sample selection.

The $\mathrm{FEV}_{1} / \mathrm{FVC}$ was significantly lower in the ICS-VE group, with a value of $67.9 \pm 2.3$, in comparison to the higher value 
of $73.5 \pm 2.4$ in the ICS+VE group, with a $\mathrm{p}$ value of $<$ 0.0005. The level of hs-CRP was significantly more elevated in the ICS-VE group $(2.7 \pm 0.3 \mathrm{mg} / \mathrm{dl})$ in comparison to the ICS+VE group $(1.3 \pm 0.1)$, with a p value of $<0.0005$. The level of hs-CRP of the ICS-VE group was also significantly higher than that of the control group $(0.5 \pm 0.2 \mathrm{mg} / \mathrm{dl})$, with a $\mathrm{p}$ value of $<0.0005$. The difference between the ICS+VE group and control group was significant, with a $\mathrm{p}$ value of $<0.05$. The relationship between hs-CRP and $\mathrm{FEV}_{1} / \mathrm{FVC}$ in the ICS-VE and ICS+VE groups was an inverse relationship, with $\mathrm{r}=-0.891$ (Pearson correlation) and a significant $\mathrm{p}$ value of $<0.0005$, reflecting a higher degree of airway obstruction in the ICS-VE group due to a lack of inhaled corticosteroid use.

The symptoms of asthma (coughing, wheezing, chest tightness, and early morning awakening) were significantly higher in the ICS-VE group $(77.3 \%$ with significant symptoms vs. $22.7 \%$ without symptoms), while in the ICS+VE group, symptoms were absent in the majority of patients $(87.5 \%$ without symptoms vs. $12.5 \%$ with symptoms). The Pearson Chi-Square of asymptotic significance $(2$-sided $)<0.0005$ was found.

\section{CONCLUSION}

In inhaled corticosteroid-negative patients (ICS-VE), the level of high-sensitivity C-reactive protein (hs-CRP) was $(2.7 \pm 0.3 \mathrm{mg} / \mathrm{dl})$, which is significantly higher than that of both the inhaled corticosteroid-positive patients $(\mathrm{ICS}+\mathrm{VE})(1.3 \pm 0.1 \mathrm{mg} / \mathrm{dl})$ and the control group $(0.5 \pm 0.2 \mathrm{mg} / \mathrm{dl})$, with a $\mathrm{p}$ value of $<0.0005$. The level of hs-CRP in ICS+VE patients was significantly higher than that of the control group, with a $\mathrm{p}$ value of $<0.05$. The values of the PFT ( $\mathrm{FEV}_{1} / \mathrm{FVC}$ ) as a measure of the degree of airway obstruction were significantly lower in the ICS-VE group in comparison to the ICS+VE group, correlating inversely with the values of hs-CRP levels. The prevalence of clinical signs and symptoms was significantly higher in the ICS-VE group in comparison to the ICS+VE group.

\section{RECOMMENDATIONS}

1. High-sensitivity CRP can be integrated into the evaluation workup for patients with asthma, especially poorly controlled asthma as a marker of systemic inflammation and for indirectly reflecting the degree of airway inflammation.

2. Emphasizing the important role of inhaled corticosteroids in controlling asthma and reducing disease severity.
3. Further studies are required to better elucidate the clinical significance of the association of highsensitivity C-reactive protein and asthma, especially its responsiveness to therapeutic protocols.

\section{ETHICAL STANDARDS}

All procedures in this study were in accordance with the ethical standards of the responsible committee on human experimentation in Iraq and the region of the Middle East, and in accordance with the Helsinki Declaration of 1975, as revised in 1983.

\section{REFERENCES}

1. Mason RJ, Broaddus VC, Martin T, King Jr TE, Schraufnagel D, Murray JF, et al. Murray and Nadel's textbook of respiratory medicine: 2-volume set. Elsevier Health Sciences, 2010.

2. Drezen JM. Asthma. In: Goldman L, Ausiello D, eds. Cecil medicine. 23 ${ }^{\text {rd }}$ ed. Saunders Elsevier, 2008, pp 613-614.

3. Barnes PJ. Asthma. In: Fauci AS, Kaspen DL, Longo DL, Braunwald E, Hausen SL, Jameson L, et al., eds. Harrison's principles of internal medicine. $17^{\text {th }}$ ed. McGraw-Hill, 2008, pp 1597-1605.

4. Diagnosis and treatment of asthma. In: Crado JD, Glassroth J, Karlinsky J, King TE, JR., eds. Baum's textbook of pulmonary disease. $17^{\text {th }}$ ed. Lippincott Williams, 2004, pp 180.

5. Colledge NR, Walker BR, Ralston S, and Davidson S. In: Davidson's principles and practice of medicine. Churchill Livingstone, 2014.

6. Grippi M, Elias J, Fishman J, Pack A, Senior R, and Kotloff R. Fishman's pulmonary diseases and disorders, 2-volume set. McGraw Hill Professional, 2015.

7. Kamath DY, Xavier D, Sigamani A, and Pais P. High sensitivity C-reactive protein (hsCRP) \& cardiovascular disease: an Indian perspective. Indian J Med Res 2015; 142(3): 261-8.

8. Kony S, Zureik M, Driss F, Neukirch C, Leynaert B, and Neukirch F. Association of bronchial hyperresponsiveness and lung function with C-reactive protein (CRP): a population based study. Thorax 2004; 59(10): 892-6.

9. Razi E, Ehteram H, Akbari H, Chavoshi V, and Razi A. Evaluation of high-sensitivity C-reactive protein in acute asthma. Tanaffos 2012; 11(1): 32-7.

10. Shimoda T, Obase Y, Kishikawa R, and Iwanaga T. Serum highsensitivity C-reactive protein can be an airway inflammation predictor in bronchial asthma. Allergy Asthma Proc 2015; 36(2): e23-8.

11. Chapman S, Robinson G, Stradling J, and West S. Asthma. In: Chapman S, Stradling J, West S, eds. Oxford handbook of respiratory medicine. $1^{\text {st }}$ ed. Oxford University Press, 2005, pp 92-102.

12. Miller MR, Hankinson J, Brusasco V, Burgos F, Casaburi R, Coates $A$, et al. Standardisation of spirometry. Eur Respir J 2005; 26(2): 319-38.

13. Walters $\mathrm{EH}$ and Walters $\mathrm{J}$. Inhaled short acting beta2-agonist use in chronic asthma: regular versus as needed treatment. Cochrane Database Syst Rev 2003; 2: D001285.

14. Vézina K, Chauhan BF, and Ducharme FM. Inhaled anticholinergics and short-acting beta(2)-agonists versus short- 
acting beta2-agonists alone for children with acute asthma in hospital. Cochrane Database Syst Rev 2014; 7: CD010283.

15. Hernández G, Avila M, Pont À, Garin O, Alonso J, Laforest L, et al. Long-acting beta-agonists plus inhaled corticosteroids safety: a systematic review and meta-analysis of nonrandomized studies. Respir Res 2014; 15(1): 83.

16. Rodrigo GJ and Castro-Rodriguez JA. Anticholinergics in the treatment of children and adults with acute asthma: a systematic review with meta-analysis. Thorax 2005; 60(9): 740-6.

17. Adkinson Jr NF, Bochner BS, Burks AW, Busse WW, Holgate ST, Lemanske Jr RF, et al. Middleton's allergy: principles and practice. Elsevier Health Sciences, 2013.

18. Rodrigo GJ and Castro-Rodríguez JA. Daily vs. intermittent inhaled corticosteroids for recurrent wheezing and mild persistent asthma: a systematic review with meta-analysis. Respir Med 2013; 107(8): 1133-40.
19. Shepherd J, Anderson R, Rogers G, Thompson-Coon J, Liu Z, Hartwell D, et al. Systematic review and economic analysis of the comparative effectiveness of different inhaled corticosteroids and their usage with long-acting beta2 agonists for the treatment of chronic asthma in children under the age of 12 years. Gray Publishing, 2008.

20. Beckhaus AA, Riutort MC, and Castro-Rodriguez JA. Inhaled versus systemic corticosteroids for acute asthma in children. A systematic review. Pediatr Pulmonol 2014; 49(4): 326-34.

21. Sridhar AV and Mckean M. Nedocromil sodium for chronic asthma in children. Cochrane Database Syst Rev 2006; 3: CD004108.

22. Ramirez D, Patel P, Casillas A, Cotelingam J, Boggs P, and Bahna SL. Assessment of high-sensitivity C-reactive protein as a marker of airway inflammation in asthma. Ann Allergy Asthma Immunol 2010; 104(6): 485-9.

Authors Contribution:

Muhammed Saleh Najdat - Concept and design of the study, data collection, statistical analysis and data interpretation, preparation of manuscript's initial drafts. Ahmed Muhammed Lutfi - Concept and design of the study, Literature review and critical revision of the manuscript.

Source of Support: No external funding, this study was completely self-funded. Conflict of Interest: None. 